From the amount of officialism to be expended on each stage of the inquiry, it is evident that Dr. Drage's scheme would defeat rather than assist the end it appears to have in view. I am, Sirs, yours faithfully, F. ROWLAND HUMPHREYS.

Fellows-road, South Hampstead, N.W., June 11th, 1895.

\section{THE ROYAL COLLEGE OF SURGEONS IN} IRELAND AND THE APOTHECARIES' HALL OF IRELAND.

\section{To the Editors of THE LANCET.}

Sirs,-As some misapprehension seems to exist regarding the report of the visitors to the examinations of the Conjoint Board of the Royal College of Surgeons and the A pothecaries' Hall of Ireland, it is necessary shortly to state the facts. Under the Medical Act of 1886 it became necessary to form a union between varions licensing bodies for the purposes of examination. Such a junction was effected and still exists between the Royal College of Surgeons in Ireland and the Royal College of Physicians. The Apothecaries' Hall then established its right to give a diploma which could be registered, and to do this it was necessary that there should be an examination in surgery. That body had been left out of the combination of the College of Physicians and the College of Surgeons, and in accordance with its right it applied to the General Medical Council for leave to appoint examiners in surgery, and permission was granted in May, 1887. It was, however, deemed inadvisable that an independent licensing body of this kind should continue in Ireland, and after negotiations the College of Surgeons entered into a conjunction with the Apothecaries' Hall to examine candidates apart from the union with the College of Physicians. Examiners were appointed, partly by the College of Surgeons and partly by the Apothecaries' Hall ; but upon reports made by the visitors of the General Medical Council the Council of the College of Surgeons decided by vote on June 22nd, 1894, to terminate the arrangement at the close of one year. It was, however, agreed that all candidates who had passed part of the examinations should have their rights preserved and should be examined so long as they presented themselves.

The examinations have been very closely inspected and freely reported upon. The last report of the visitors (April and May, 1895) describes the first professional examination as "a good and satisfactory test"; in the second the examination in anatomy and materia medica and pharmacy as "commendable"; and of the third it declares that "no exception could be taken to any part of this examination." Of the final examination the visitor and inspector report an "improvement generally." At this examination the examiners in medicine are appointed by the Apothecaries' IHall, and in surgery by the College of Sargeons. In all the other subjects, save medicine, the visitors state that the examination was "sufficient," and of the examination in medicine it is right to say that the visitors differ from the examiners in one point only, and that they declare that the "examination was a most careful one, and, we believe, was conscientiously conducted." It was upon this report that the Medical Council agreed to bring this conjoint scheme before the Privy Council as insufficient. What we desire to show is that the work of the College of Sargeons in this connexion has been properly carried out and to make it known that the partnership is on the eve of dissolution. There is no examination in the world with which faults of different kinds may not be found by so many different visitors. For many years the examinations of this College, as of all others in the United Kingdom, have been reported on, and we have received frequent commendation. The College endeavours to maintain a high standard; in certain senses its examinations are in advance of those of other countries, and in this last report we have again obtained the approval of the visitors.

We ought, perhaps, again to point out that the union between the College of Physicians and the College of Gargeons continues as before, and that the examinations have been declared to be, in the words of the Act, "sufficient."

W. Thornley STOKkR, President.

William Thomson, Vice-President. ROBERT H. WOODS, Sec. of Council.

\section{VISION IN ELEMENTARY SCHOOLS :} A REQUEST.

\section{To the Editors of THE LANCET.}

SIRs - Will you permit me to say through your columns that I bave undertaken, in conjunction with a committee of the Education Department, to investigate the state of vision among the children in elementary schools, and that I shall be very glad to obtain the help of competent volunteers in carrying out this undertaking? Any gentlemen accustomed to estimate refraction, and able to spare a couple of afternoon hours on stated days, will much oblige by com municating with me at 31 . Harley.street, W. I propose to ascertain the percentage of children with subnormal vision and the cause to which in each case the subnormality is to be ascribed. I should, perhaps, add that my own work in the matter will be unpaid, and that I am consequently unable to offer payment to those who may be good enough to assist me.

I am, Sirs, your obedient servant,

Harley-street, W., June 18th, $1895 . \quad$ R. BRUdENELL CABTER.

\section{THE REMUNERATION OF MEDICAL} OFFICERS TO PROVIDENT ASSOCIATIONS, CLUBS, ETC.

\author{
To the Editors of THE LANCET.
}

SIRS -The paper of Mr. F. R. Humphreys, read before the Hunterian Society, on the Necessity for a Central Organisation in the Medioal Profession, and the publication in The LANCET of Jane 8th of the Hospital Sunday Committee, render the above subject peculiarly interesting just now. I hope, therefore, you can fird room for what must, from the nature of the subject, be a long letter. Some years ago you did me the bonour to publish a letter regarding the general income of the profession, which led to such a long discussion as proved this to be a burning question. For years past the number of qualifications granted has exceeded the retirements from the medical profession by some 600 a year. This means in a single generation an increase of 18,000 in the number of medical men. It is no wonder, therefore, that medical practitioners are tempted to nndersell one another. According to Mr. Neison's statistics of the sickness experienced in the Manchester Unity of Oddfellows, one may expect in patients between the ages of twenty-one and sixty-five an average of one month's sickness per head per annum, which, I think, may be taken as equivalent to fifteen visits. As the present payments range from $3 s .6 d$ to $6 s$. a year (most usually $4 s$. or 4s. 4d.) we may consider the scale of payment to medical officers of provident dispensaries, friendly societies, \&c., as about $3 d$. a visit, including medicine. I think parochial medical men get less even than this, but it is difficult to compute. It seems to me that no contribution is worthy of the name of " provident," in which the scale of pay is so inadequate that it would be impossible for a man devoting his whole time to the work to make the poorest living commensurate with his class of life. Let us see how $3 d$. a visit works out We will even assume that the present scale of payments would allow of $1 d$. for each consultation at the surgery as well as $3 d$. for each visit at the patient's house. We will assume that poor people live close together and can be seen at the rate four visits (or twelve consultations) an hour. It is only in towns that such an assumption would hold good. As eight hours is considered a working man's day, we will take eight hours as a just day's work for a medical man of which six are spent in visiting and midwifery and two in home consultations and dispensing. Thus we have-

$$
\begin{aligned}
& \text { Six hours, at four visits per hour at } 3 d \text {. each } \begin{array}{cc}
s . & d . \\
6 & 0
\end{array} \\
& \text { Two hours, at twelve consultations per hour } \\
& \begin{array}{lllllllllllll}
\text { at } 1 d . \text { each } & \ldots & \ldots & \ldots & \ldots & \ldots & \ldots & \ldots & \ldots & 2 & 0-8 & 0
\end{array} \\
& \text { Deduct for expenses- } \\
& \text { Use of furnished waiting-room and sur- } \\
& \text { gery, with fires, lights, and attendance, } \\
& \text { Thirty bottles of medicine } \ldots \text { at } \ldots \ldots \text {. } \ldots \text { each } \\
& \text { (cost price)... }
\end{aligned}
$$

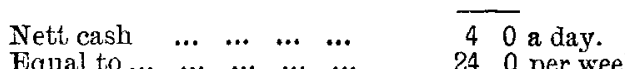

Twenty-four shillings a week is not the pay of a skilled mechanic, and you will grant that I have estimated the working expenses at too low a figure. Nor have I reckoned anything for interest on or recovery of capital sunk in obtaining 